University of Nebraska - Lincoln

DigitalCommons@University of Nebraska - Lincoln

Faculty Publications from the Harold W. Manter Laboratory of Parasitology

$11-1949$

\title{
Observations of the Life Cycle and Larval Development of Paruterina candelabraria (Goeze, 1782) (Cestoda: Dilepididae)
}

Robert L. Rausch

University of Washington, rausch@u.washington.edu

Follow this and additional works at: https://digitalcommons.unl.edu/parasitologyfacpubs

Part of the Parasitology Commons

Rausch, Robert L., "Observations of the Life Cycle and Larval Development of Paruterina candelabraria (Goeze, 1782) (Cestoda: Dilepididae)" (1949). Faculty Publications from the Harold W. Manter Laboratory of Parasitology. 570.

https://digitalcommons.unl.edu/parasitologyfacpubs/570

This Article is brought to you for free and open access by the Parasitology, Harold W. Manter Laboratory of at DigitalCommons@University of Nebraska - Lincoln. It has been accepted for inclusion in Faculty Publications from the Harold W. Manter Laboratory of Parasitology by an authorized administrator of DigitalCommons@University of Nebraska - Lincoln. 


\title{
Observations of the Life Cycle and Larval Develop- ment of Paruterina candelabraria (Goeze, 1782) (Cestoda: Dilepididae) ${ }^{1}$
}

\author{
Robert Rausch 2 \\ Department of Veterinary Science, University of Wisconsin, Madison
}

Paruterina candelabraria (Goeze, 1782) is parasitic in owls in Europe and North America, and appears to be the most frequently encountered cestode occurring in strigiform birds (Wolffhügel, 1900; Rausch, 1948). It is the purpose of this paper to present observations on the larval development and life cycle of $P$. candelabraria. Apparently nothing is known concerning the life cycles of cestodes of the genus Paruterina Fuhrmann, 1906, most of which occur in passeriform birds.

During the spring of 1948 , the author succeeded in obtaining the larvae of Paruterina candelabraria experimentally in three laboratory mice (Rausch, 1948). Extremely heavy liver infections were observed when the mice were killed and examined a month after the infection attempt (plate I, fig. 1). Part of the infected livers were fed to a captive great horned owl, Bubo v. virginianus (Gmelin), but no cestodes were recovered when the bird was autopsied a month later. Attempts to infect a grey squirrel, Sciurus carolinensis leucotis Gapper, at the same time were unsuccessful.

The study of the infected mouse-liver sections disclosed that the larvae were cysticercoids (plate II, figs. 1 and 2)-a larval type of unusual occurrence in mammalian tissue. In order to make possible additional observations, an attempt was made to obtain material that would allow the infection of a larger number of experimental animals. We were particularly interested in attempting the infection of certain native mice which, in the region where this work was done, form the bulk of the food of the larger owl species.

Through the generous cooperation of Mr. Stephen H. Richards, Wildlife Biologist with the Wisconsin Conservation Department, a second naturallyinfected owl was obtained during the fall of 1948, and the gravid segments from 4 worms were used to infect experimental animals.

The mammals used for this work were anesthetized and given one gravid segment each by means of a stomach tube. Thirty-six laboratory mice, from 17 to 20 days old, were infected, as were hamsters, chipmunks, Tamias striatus L. ssp., white-footed mice, Peromyscus maniculatus bairdii Hoy and Kennicott, and a single meadow vole, Microtus $p$. pennsylvanicus Ord. It was at first the intention to kill the white mice every second day, in order to observe

1 Published with the approval of the Director of the Wisconsin Agricultural Experiment Station.

2 Now with the U. S. Public Health Service, P. O. Box 960, Anchorage, Alaska. 
Rausch in American Midland Naturalist (November 1949) v. 42, no. 3.

Copyright 1949, University of Notre Dame. Used by permission.

larval development; however, this development took place with such rapidity that, after the first few days, mice were killed daily.

Four mice, killed and examined for infection on the 21st day, were found heavily infected, and were fed to a captive great horned owl. The owl was

\section{Plate I}

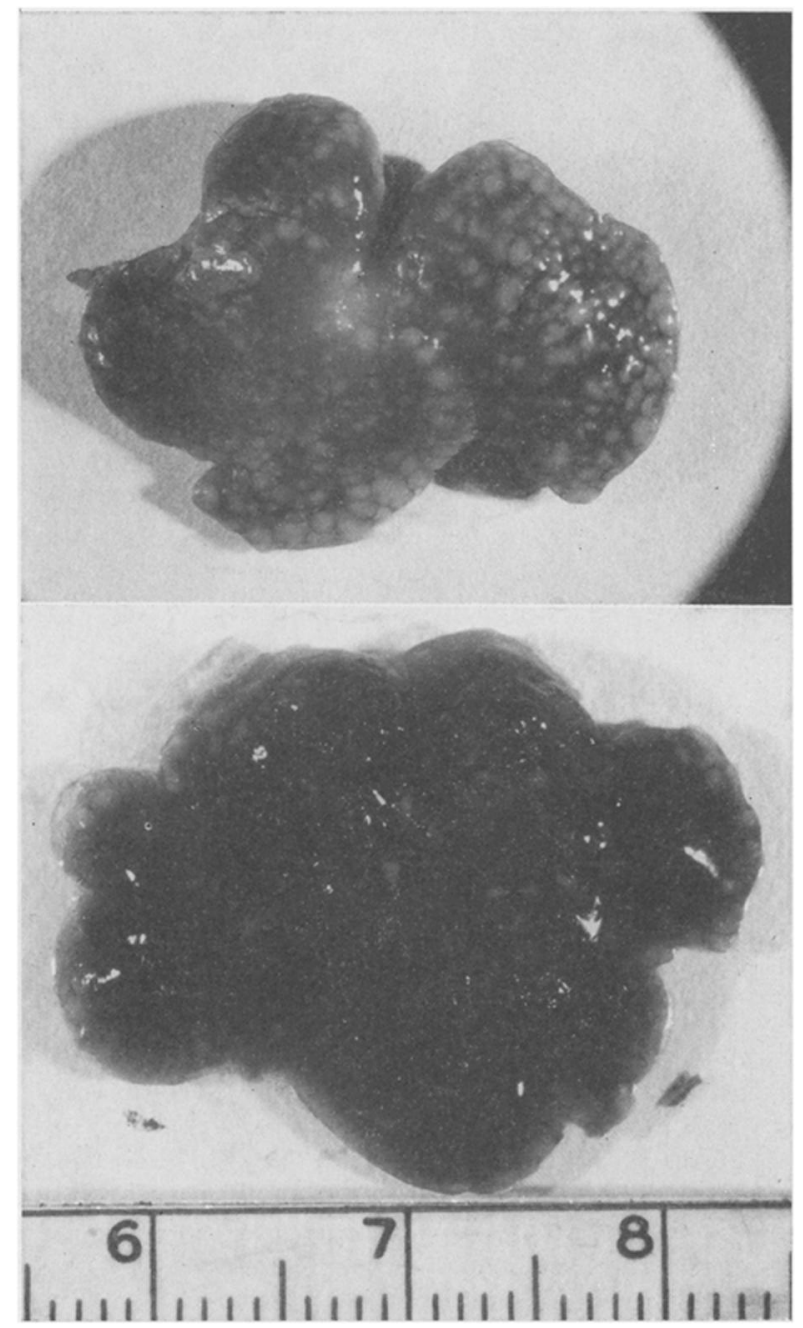

Fig. 1.-Liver of laboratory mouse showing severe infection with Paruterina candelabraria larvae (upper). Photograph taken 30 days after experimental infection.

Fig. 2.-Liver of laboratory mouse showing moderate infection with Paruterina candelabraria larvae. Photograph taken 30 days after experimental infection. 
killed on the 7th day after this feeding, and more than 60 specimens of Paruterina candelabraria were removed from the small intestine. These worms were immature, and measured about $12 \mathrm{~mm}$. in length. The owl used for this experiment had been a captive for more than 6 months, and during this time had been given only a prepared fox food. There was no opportunity for its becoming infected with the species of cestode with which we are concerned.

As the mice were killed daily, their livers (the only part of the body infected by larvae of Paruterina candelabraria) were fixed in either alcohol-acetic acid-formalin solution, or in 10 per cent formalin. In a few cases special fixatives were used. The sections were routinely stained with Crossman's modification of Mallory's triple stain, and special methods were used for the determination of certain specific details. An effort was made to follow the cellular reaction of the host tissue to the larvae during the course of their development.

The experimental animals were infected on September 29, and the first mouse was examined on the second day after infection. The liver of this animal showed no gross changes. The liver of the animal killed on the third day showed numerous small hemorrhages on the surface of the liver. There was considerable congestion, probably as a result of larval migration through the blood vessels of the liver. The larvae were clearly visible on the surface of the liver by the 6th day, when they were seen as white spots measuring from 0.5 to $1.5 \mathrm{~mm}$. in diameter. By the 8th day the larvae were larger and more obvious. Larvae were observed only in the peripheral part of the liver, regardless of the severity of the infection. However, with extremely heavy infections (plate I, fig. 1) the connective tissue capsules surrounding the larvae coalesce, and raised areas on the surface of the liver were commonly seen. Moderate infections had much the same gross appearance as liver infections by the cysticerci of Cladotaenia spp. However, they can be microscopically differentiated at the time they are dissected from the host tissue-the cysticerci being readily recognized as such.

Microscopically, considerable hyperemia was seen in the liver of the mouse killed on the second day after infection. In some areas hemorrhage was evident. The liver obtained on the third day showed areas of infiltration by neutrophile and mononuclear cells, and there were scattered peripheral foci of beginning necrosis. By the 6th day peripheral areas of necrosis, surrounded by inflammatory cells in which macrophages were predominant, were much in evidence. Damaged liver cells were seen within the necrotic areas, and small larvae were occasionally observed within the capillaries. The irregular congestion observed at this stage of larval development was perhaps caused by the localization of the larvae, in contrast to the generalized hyperemia seen earlier. Necrosis had become more extensive by the 8th day; neutrophiles were more numerous, and the mononuclear cells had almost disappeared from some areas. By this time the larvae had migrated deeper into the liver tissue, leaving behind them rather extensive areas of necrosis. Little reaction was observed around the parasites, which had migrated inward away from the peripheral areas of necrosis. There was little change in the necrotic areas.

After the 10th day, there was little change around the larvae themselves 
Rausch in American Midland Naturalist (November 1949) v. 42, no. 3.

Copyright 1949, University of Notre Dame. Used by permission.

\section{Plate II}
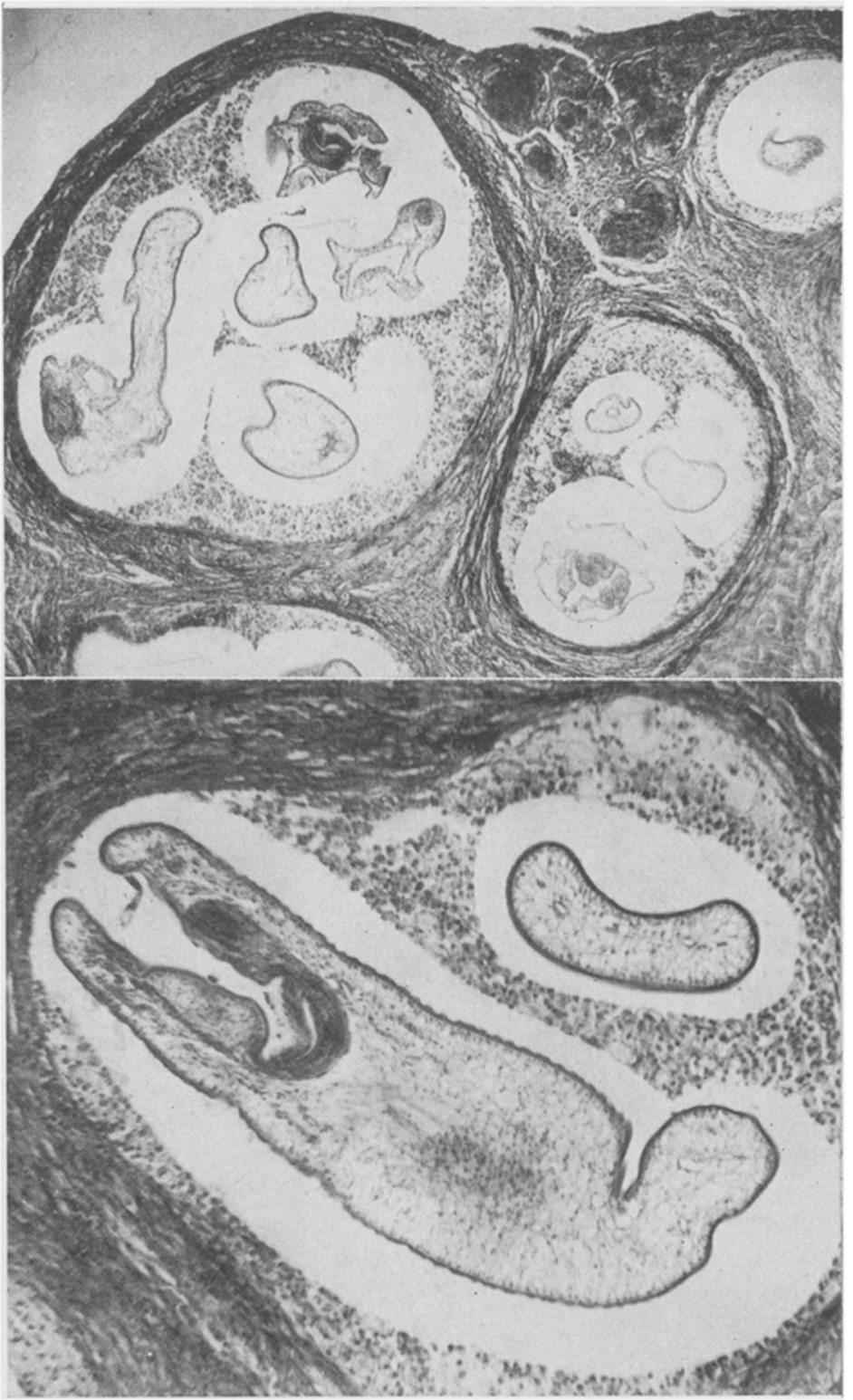

Fig. 1.-Photomicrograph, taken 30 days after infection, of liver of laboratory mouse infected with cysticercoids of Partuterina candelabraria (upper). This section was made from the same organ shown in plate I, fig. 1. Low power.

Fig. 2.-Photomicrograph, taken 30 days after infection, of a single cysticercoid of Paruterina candelabraria in the liver of an experimentally infected laboratory mouse. Typical larval form and macrophages lining connective tissue capsule are shown. Medium power. 
except for a gradual proliferation of the connective tissue capsule. The trail of the parasite persisted as an area of fibroblastic infiltration, with some lymphocytes and atrophy of adjacent liver cells. About the 12th day a considerable amount of yellow pigment was observed in the Kupffer cells, particularly in areas near the parasites. The Gmelin Reaction was not obtained for hematoporphyrin or bilirubin, and the test by Turnbull's method for hemosiderin was also negative. By the 18th day the fibrosis around the parasites was zather extensive; polymorphs were numerous and macrophages, with their cytoplasm filled with granules, were abundant within the capsules near the parasites. On the 22nd day foam cells (plate III, fig. 1) were noted near the parasites. These were at first thought to be macrophages which had phagocytized fat, but suitable stains failed to demonstrate any fat. For this information, the livers were frozen-sectioned and stained with Sudan IV by the Lillie method, and also by the osmium tetroxide method. The yellow pigment persisted in the Kupffer cells in the proximity of the larvae. The toluidin blue test for mast cells and the Unna-Pappenheim plasma cell stain both gave negative results.

The connective tissue capsule reached maximum thickness by the 30th day. It averaged about $70 \mu$ in thickness at this time. There seemed to be little or no change in this as late as the end of the second month after infection. At 30 days the capsule, containing the larva, measured about 850 by 550 $\mu$, and the undisturbed larva measured about 700 by $280 \mu$.

After the 15th day it was noted that macrophages were numerous within the connective tissue capsule surrounding the parasite (plate II, figs. 1 and 2; plate III, fig. 1). These cells persisted in this location for at least 60 days after infection - as long as observations were made. In the mice, however, there was never any invasion of the parasites.

In other mammalian species.-The infection in the hamsters took the same course as that in laboratory mice. That seen in the white-footed mice also did not differ in any appreciable way. The single vole infected died on the second day after infection. The liver of this animal showed congestion comparable to that seen in laboratory mice in the early stages of the infection. Since voles may die rather frequently when kept under laboratory conditions, we do not consider the death of this animal to be connected in any way with the parasite infection. It might be mentioned here that in no case, regardless of severity of infection, was there any recognizable effect on the physical condition of the infected animals.

Only two chipmunks were infected, so observations on this species are limited. However, when a heavily-infected animal was examined on the 21st day, the host tissue-reaction appeared to be much more severe than any seen in the other mammals. Although the larvae had migrated away from the peripheral areas of necrosis, they were closely surrounded by the tissue reaction (plate III, fig. 2). Giant cells (plate III, fig. 2), unobserved in the other mammals, were common. The question arises as to whether the larvae might not be destroyed by the tissue reaction of the chipmunk. As discussed further below, it is improbable that the chipmunk would serve as a suitable intermediate host for this owl cestode. 
Rausch in American Midland Naturalist (November 1949) v. 42, no. 3.

Copyright 1949, University of Notre Dame. Used by permission.

\section{Plate III}
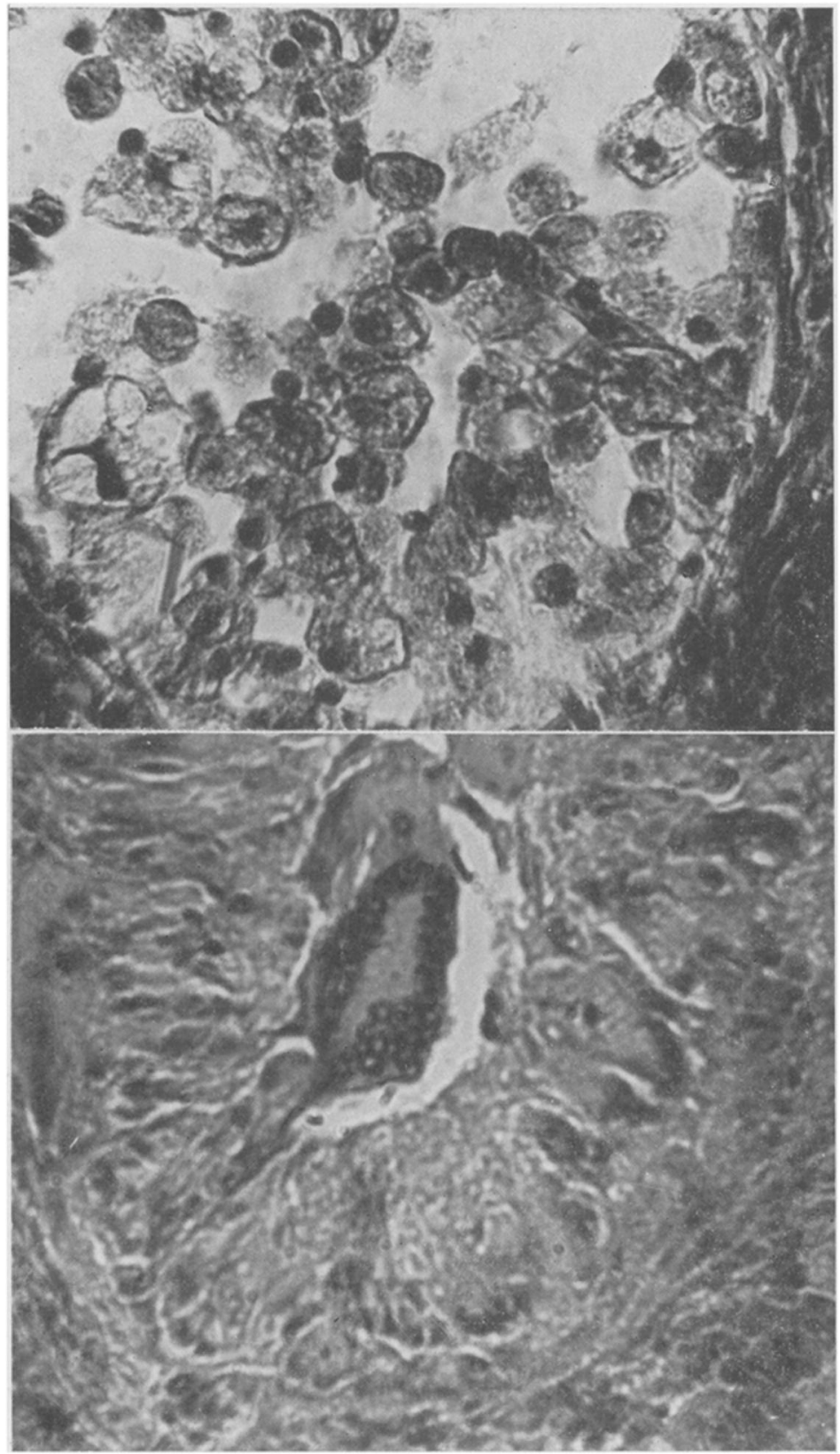

Fig. 1.-Foam-cell macrophages within fibrous connective tissue capsule surrounding larvae (upper). High power.

Fig. 2.-Tissue reaction of chipmunk to larvae of Paruterina candelabraria. Necrotic tissue is abundant, and a multinucleated giant cell is shown near top of section. Medium power. 


\section{Discussion}

An effort was made to compare the tissue reaction of mammals infected with the larvae of Paruterina candelabraria with that seen in similar infections by other cestode species. It might be of some value to mention these briefly.

Taenia taeniaeformis larvae.-An early infection by the strobilocercus of this cestode in the liver of a laboratory mouse was studied. A very thick cyst wall composed of fibrous connective tissue was seen. Within the capsule, and lining its wall, were numerous lymphocytes and macrophages. Some of the latter contained a yellow pigment within their cytoplasm, and others contained a granular material. There appeared to be considerable pressure atrophy of the liver cells adjacent to the capsule surrounding the parasite. The surrounding tissue also contained a considerable amount of yellow pigment, within the cytopasm of the Kupffer cells.

We did not examine histologically any infections by this larval cestode in voles, but some observations were made on an old infection in the liver of a muskrat, Ondatra z. zibethica L. A rather thick layer of calcium deposit was seen around the parasite, and surrounding this was a layer of fibrous connective tissue. Outside the connective tissue capsule were seen early deposits of calcium. The adjacent liver tissue was necrotic. A yellow pigment was abundant in the Kupffer cells, in the damaged as well as in the adjacent normal areas. Foam cells were not observed. Athough in some areas the calcium deposits were in direct contact with the cestode, the latter showed no apparent sign of invasion or damage.

Unidentified cestode larvae-Cestode larvae, thought first to be Taenia sp., were taken from the liver of a snowshoe hare, Lepus americanus Erxleben, collected in central Manitoba. Although we were unable to assign these larvae to genus, it seems of value to discuss here the reaction brought about by their invasion of the liver tissue of the hare. Large areas of necrosis, surrounded by lymphocytes and fibrous connective tissue, were numerous. In some lesions, possibly earlier ones, giant cells, macrophages, and polymorphonuclear leucocytes were seen. Pigment was abundant in the Kupffer cells near the necrotic lesions. Chronic passive hyperemia was noted. The liver sinusoids in areas adjoining the recently-invaded areas were filled with macrophages and polymorphonuclear leucocytes. Some eosinophiles were present. No foam cells were seen.

Cladotaenia sp.-During November, 1948, at Madison, Wisconsin, an adult vole infected with 10 cysticerci of Cladotaenia sp. was collected. The cysticerci were closely encapsulated by fibrous connective tissue. There was some atrophy of the liver cells, and fibroblasts closely surrounded the parasites. There was a moderate infiltration of lymphocytes around the fibroblastic layers. Calcium was deposited around the greater part of each parasite, and cells were seen entrapped within the calcium. The Kupffer cells throughout the liver were filled with a brown, granular pigment, but it was most abundant in the areas surrounding the parasites. There was a chronic passive congestion, and considerable vacuolation of the liver-cell cytoplasm around the parasites. 
It is apparent from the foregoing that the tissue reaction to the invasion by the cysticercoids of Paruterina candelabraria does not appear to differ significantly from reactions seen in other host species invaded by larval cestodes of other genera.

Certain of the native North American mice (Cricetidae) form a very considerable part of the diet of owls. The house mouse, not a native form, is also preyed upon. It is interesting that a natural infection by Paruterina candelabraria has never been reported from rodent intermediate hosts. The author has examined to date a total of 744 specimens of the common meadow vole, and 240 specimens of white-footed mice, all from the North Central States region, and a considerable number of similar rodents from other regions as well. In the North Central States, about 6 per cent of the large owls (Strix and $B u b o$ ) harbour P. candelabraria in the small intestine (Rausch, 1948). Although the distribution of this larval cestode in the liver of the intermediate host appears to be such that they would be easily seen, we have failed to detect a single natural infection.

It might be of value to compare incidence of infection of another cestode parasitic in raptors. In the same region (North Central States) Cladotaenia spp., the common cestodes of hawks, are often seen as cysticerci in the liver of voles. According to our records, about 16 per cent of the large hawks (Buteo) harbour this cestode, and its larvae are found in 3 per cent of the voles. There should be little difference in the detectability of the two species of larvae, since both are situated in the host liver, and they are of similar size. However, many factors are involved, such as relative densities of definitive and intermediate hosts, habitat differences, and the like.

It is almost certain, from indirect evidence, that insects act as the intermediate hosts for cestodes of this genus found in passeriform birds. We were unable to infect beetles (Tenebrio) with Paruterina candelabraria, but further experiments of this type might be of interest. Certain owl species feed to a large degree upon insects.

It is questionable that chipmunks and probably other sciurids would act as suitable intermediate hosts for Paruterina candelabraria. Even if the tissue reaction of the host does not have a detrimental effect upon the cysticercoids, there would be relatively' little opportunity for owls to become infected from squirrels, since these diurnal mammals do not form a very considerable part of their diet. It might be of some interest to attempt infection experiments with various species of shrews, especially Blarina. However, the few hundred shrews of various species for which we have records have disclosed no cestode larvae of this type.

\section{SUMMARY}

The life cycle of Paruterina candelabraria (Goeze, 1782), a cestode parasitic in owls, has been experimentally completed. Rodents serve as the intermediate host. Hamsters, white-footed mice, and laboratory mice were successfully infected, and the infection was transmitted to an owl by feeding heavily infected mice. The cysticercoids of Paruterina candelabraria develop in the 
Rausch in American Midland Naturalist (November 1949) v. 42, no. 3.

Copyright 1949, University of Notre Dame. Used by permission.

liver of the intermediate host. Histopathological changes resulting from infection with cysticercoids of $P$. candelabraria were compared with changes caused by larvae of other cestode genera, and were found to be similar.

\section{ACKNOWLEDGMenT}

The writer wishes to express his indebtedness to Dr. Louise A. Lombard for her aid in connection with the histopathological part of this work, and without which this work could not have been completed.

\section{REFERENCES}

RaUsCH, R. 1948-Observations on cestodes in North American owls, with the description of Choanotaenia speotytonis n. sp. (Cestoda: Dipylidiinae). Amer. Midl. Nat. 40: $462-471$.

WolfFHÜgEL, K. 1900-Beitrag zur Kenntnis der Vogelhelminthen. Inaug. Diss. Basel. 204 pp. 